\title{
Kelemahan Dasar Pokdarwis Wonderful Dalam Pengembangan Pariwisata Di Kawasan Situs Manusia Purba Sangiran
}

\author{
Yudhi Van Stepan Simorangkir ${ }^{1}{ }^{*}$, Wilson Therik ${ }^{1}$, Widhi Handayani ${ }^{1}$ \\ ${ }_{1}^{1}$ Universitas Kristen Satya Wacana, Indonesia
}

\author{
A R T I CLE I N F O \\ Article history: \\ Received 23 Oktober 2020 \\ Accepted 10 Desember \\ 2020 \\ Available online 31 \\ Desember 2020 \\ Kata Kunci: \\ Pokdarwis; Pengembangan \\ Pariwisata; Partisipasi; \\ Inovasi; Sangiran \\ Keywords: \\ Pokdarwis;Development \\ Tourism; Participant; \\ Inovation; Sangiran
}

\begin{abstract}
A B S T R A K
Tujuan penelitian ini untuk mengindentifikasi masalah-masalah yang dihadapi oleh Pokdarwis Wonderful dan mengusulkan solusi guna meningkatkan kinerja Pokdarwis Wonderful dalam pengembangan kepariwisataan di Situs Manusia Purba Sangiran. Penelitian ini menggunakan metode penelitian kualitatif yang berlandaskan studi kasus. Pengumpulan data dilakukan dengan metode wawancara yang mendalam dan observasi. Teknik analisis dan strategi validitas data menggunakan metode triangulasi. Hasil penelitian ini menunjukkan adanya isu dan konflik dalam organisasi Pokdarwis Wonderful dalam mengembangkan kepariwisataan Sangiran, ditambah ketidak mampuan pengurus dalam menyelesaikan masalah, berpengaruh kepada minimnya tingkat partisipasi masyarakat lokal bergabung ke organisasi Pokdarwis Wonderful. Sementara itu, rendahnya inovasi dan kreativitas organisasi Pokdarwis Wonderful yang hanya mengelola beberapa bagian dari museum Manusia Purba Sangiran menjadi masalah dalam pengembangan kepariwisataan di Sangiran. Beberapa kendala tersebut berkaitan dengan masalah internal organisasi Pokdarwis Wonderful yang pada akhirnya juga berdampak pada pengembangan kerja sama dengan lembaga lain.
\end{abstract}

\section{A B S T R A C T}

The research is to identify the problems faced by Pokdarwis Wonderful and to propose solutions to improve the performance of Pokdarwis Wonderful in tourism development at Sangiran Early Man Site. This research uses qualitative research methods based on case studies.The data was collected by using in-depth interviews and observation.The analysis technique and data validity strategy used the triangulation method. The results of this study indicate the existence of issues and conflicts in the Pokdarwis Wonderful organization in developing Sangiran tourism, plus the inability of the management to solve problems has an effect on the minimum level of participation of local people in joining the Pokdarwis Wonderful organization. Meanwhile, the low innovation and creativity of the Pokdarwis Wonderful organization which only manages a few parts of the Sangiran Early Man Museum has become a problem in tourism development in Sangiran. Some of these obstacles are related to internal problems of the Pokdarwis Wonderful organization which in the end also have an impact on developing cooperation with other institutions.

\footnotetext{
* Corresponding author.

E-mail addresses: yudhisimorangkir15@gmail.com
} 


\section{Pendahuluan}

Secara umum Sangiran merupakan ladang temuan fosil hewan purbakala, manusia purba, lapisan tanah, evolusi lingkungan, arkeologi dan geologi. Kekayaan fosil tersebut merupakan warisan masa lampau yang diwariskan kepada generasi sekarang untuk merawat dan mempertahankan temuan fosil yang bernilai tinggi demi kemajuan ilmu pengetahuan. Widianto et al. (2011) menyatakan bahwa Sangiran memiliki kandungan fosil dan potensi kuat atau daya tarik Sangiran terletak pada kandungan fosil-fosil hewan maupun manusia purba dan peralatan batu serta terdokumentasikannya lapisan tanah (stratigrafi) yang tidak terputus sejak dua juta tahun yang lalu. Demikian juga Sémah et al.(1990) menyatakan pada masa itu sudah ada seorang budayawan Indonesia, yaitu Raden Saleh, seorang pelukis yang tertarik akan keberadaan tulangtulang raksasa atau fosil yang di kala itu disebutnya sebagai Balung buta.

Keberadaan tulang-tulang ini telah menarik perhatian para peneliti asing untuk melakukan penelitian di kawasan Situs Sangiran. Sejak saat itu masyarakat di kawasan Sangiran mulai memahami penggalian fosil karena mereka dilibatkan oleh para peneliti asing. Kegiatan penelitian yang dilakukan di kawasan situs Sangiran telah memberi dampak yang signifikan pada pengalaman dan pengetahuan masyarakat tentang eskavasi fosil. Penelitian yang sejak awal telah melibatkan masyarakat juga berpengaruh pada persepsi masyarakat tentang nilai ekonomis dari fosil-fosil yang ditemukan dalam penggalian. Setelah silih bergantinya kedatangan peneliti asing ke Kawasan Sangiran, masyarakat semakin memahami nilai ekonomi dari fosil-fosil yang ditemukan Sulistyanto, (2009).

Menyadari hal tersebut pada tahun 1995 Pemerintah Republik Indonesia mengambil langkah untuk meminimalisir penjualan fosil secara ilegal dengan mengusulkan kawasan Sangiran yang sudah tercantum di dalam World Heritage List menjadi situs warisan dunia ke United Nation Educational, Scientific, and Cultural Organization (UNESCO). Pada tanggal 5 Desember 1996, UNESCO menetapkan kawasan Sangiran sebagai warisan budaya dunia (World Cultural Heritage) bernomor 593 yang disebut "The Early Man Site". Selain sebagai cagar budaya, situs ini memiliki potensi untuk dikembangkan menjadi objek wisata, sejarah dan pendidikan.

Dalam rangka mendukung pengembangan kawasan situs manusia purba Sangiran, maka dibutuhkan keterlibatan dan dedikasi masyarakat untuk mewujudkan Sangiran sebagai salah satu destinasi pariwisata di Provinsi Jawa Tengah. Pemanfaatan museum Sangiran berbasis kepariwisataan merupakan strategi yang diharapkan dapat meningkatkan kesejahteraan masyarakat Sangiran. Penguatan masyarakat lokal melalui pembentukan organisasi masyarakat berbasis kepariwisataan merupakan salah satu strategi yang efektif dan diharapkan mampu menemukan kembali kesadaran masyarakat lokal untuk merawat dan menjaga kandungan fosil atau peninggalan benda sejarah serta memanfaatkan potensi alam yang berada di Sangiran, untuk dikelola menjadi objek wisata.

Upaya pengembangan pariwisata di kawasan situs Sangiran menjadi hal yang penting dalam rangka pelestarian yang memberikan dampak ekonomi kepada masyarakat lokal Sangiran. Tanpa pengembangan pariwisata yang berlandaskan pada prinsip konservasi, ada kekhawatiran akan rusaknya kawasan situs dan peninggalan benda sejarah mengingat kawasan Sangiran merupakan kawasan cagar budaya yang dilindungi Undang-Undang No 11 tahun 2010 tentang cagar budaya dalam pasal 23 ayat 1 menyatakan : "Setiap orang yang menemukan cagar budaya atau yang diduga cagar budaya wajib melaporkannya kepada instansi yang berwenang dibidang kebudayaan, Kepolisian, dan/atau instansi terkait paling lama sejak 30 hari sejak ditemukannya".

Dari produk regulasi cagar budaya ini, masyarakat membutuhkan sebuah pedoman pengembangan wisata yang berlandaskan prinsip keberlanjutan ekologis dengan pengembangan masyarakat sebagai pihak penerima manfaat dari kawasan situs. Haque (2000) menjelaskan salah satu prinsip dari pengembangan masyarakat adalah prinsip keswadayaan, yang diturunkan langsung dari prinsip ekologis keberlanjutan. Keberlanjutan menuntut bahwa struktur-struktur yang dikembangkan adalah yang mampu dipelihara dalam jangka panjang, dengan meminimumkan tingkat ketergantungan dan konsumsi sumber daya.

Menurut Rahim (2012), salah satu aspek mendasar bagi keberhasilan pembangunan kepariwisataan adalah dapat diciptakannya lingkungan dan suasana kondusif yang mendorong 
tumbuh dan berkembangnya kegiatan kepariwisataan di suatu tempat. Sejalan dengan itu, sadar wisata merupakan elemen penting yang tidak dapat dipisahkan dari Sapta Pesona guna pembangunan kepariwisataan di Sangiran. Hal ini menjadi tugas organisasi Pokdarwis Wonderful untuk dapat menerjemahkan makna sadar wisata dalam bentuk agenda program kerja, sehingga filosofi sadar wisata menjadi sebuah karakter yang terpatri dalam setiap individu di Sangiran.

Dalam rangka membangun kesadaran masyarakat dan pengembangan kepariwisataan dibutuhkan sebuah wadah yang dibangun atas kesadaran dan keswadayaan masyarakat. Tujuan wadah organisasi ini untuk dapat mengembangkan pariwisata dengan prinsip kesadaran ekologis sehingga pembangunan yang dilakukan dapat berkelanjutan dan tidak merusak potensi lokal yang ada.Pengetahuan dan pengalaman yang mumpuni yang dimiliki oleh kelompok masyarakat memiliki peranan penting dalam menyadarkan masyarakat luas akan pentingnya pariwisata. Pengembangan pariwisata harus dilakukan dengan paradigma konservasi dan bukan eksploitasi seperti yang berlangsung sejak lama. Maka dibentuklah Kelompok Sadar Wisata Wonderful Sangiran (Pokdarwis) atas inisiatif masyarakat yang kemudian pada tanggal 11 November 2016 melalui Surat Keputusan Dinas Pariwisata, Pemuda, Olahraga dan Kebudayaan Kabupaten Sragen.

Namun hal tersebut tidak dapat berjalan sesuai dengan harapan karena keberadaan Pokdarwis Wonderful sejauh ini belum mampu memberikan dampak yang signifikan bagi pengelolaan dan pengembangan potensi pariwisata di Sangiran. Dari penjelasan latar belakang masalah, dapat dirumuskan dalam penelitian ini yaitu "Mengapa organisasi Pokdarwis Wonderful kurang berdampak terhadap pengembangan pariwisata di situs manusia purba Sangiran"?. Adapun tujuan penelitian ini yang ingin dicapai adalah: untuk mengidentifikasi masalah-masalah yang dihadapi oleh Pokdarwis Sangiran dan mengusulkan solusi guna meningkatkan kinerja Pokdarwis dalam pengembangan kepariwisataan di situs manusia purba Sangiran. Dari penelitian ini ada dua manfaat yaitu sebagai pengembangan sumber ilmu pengetahuan serta diharapkan mampu memberikan kontribusi dalam ilmu Studi Pembangunan, serta mampu memfasilitasi masyarakat Sangiran dalam memetakan masalah dan kendala yang dihadapi guna pengambangan kepariwisataan di Sangiran.

\section{Metode}

Metode penelitian yang digunakan adalah penelitian kualitatif yang berlandasakan studi kasus, yang di dalamnya peneliti menyelidiki secara cermat suatu program, peristiwa aktivitas, proses atau kelompok individu. Menurut Creswell (1998) studi kasus adalah sebuah eksplorasi dari "suatu sistem yang terikat" atau "suatu kasus/beragam kasus" yang dari waktu ke waktu melalui pengumpulan data yang mendalam serta melibatkan berbagai sumber informasi yang "kaya" dalam suatu konteks.

Penelitian ini mengambil sumber data untuk diwawancarai, yaitu antara lain: Ketua Pokdarwis dipilih karena penelitian ini dilakukan pada Pokdarwis Wonderful, sehingga informasi dari ketua Pokdarwis menjadi penting untuk dieksplorasi. Pemilihan subjek data Kepala Desa Krikilan dilakukan mempertimbangkan SK Legalitas sebagai salah satu pembina Pokdarwis. Dinas Pariwisata juga dipilih karena memiliki tangggung jawab dimana Dinas Pariwisata menerbitkan SK legalitas Pokdarwis Wonderful dan berada dibawah lingkungan institusi Dinas Pariwisata. Pengurus Pokdarwis Wonderful dipilih karena mereka merupakan bagian dari pengembangan wisata di kawasan Sangiran. BPSMPS dipilih karena selama ini BPSMPS berperan sebagai mitra Pokdarwis Wonderful Sangiran dalam pengembangan wisata di Sangiran serta jasa guiding dan eskavasi. Tokoh pendiri Pokdarwis Wonderful yang keluar dari organisasi dipilih guna memberikan gambaran masalah-masalah yang dihadapi Pokdarwis Wonderful. Pengurus klaster Pokdarwis Wonderful klaster museum dipilih karena dapat membantu peneliti menggali lebih dalam fakta peneltian. Pengusaha kuliner di sekitar museum dipilih karena dapat membantu untuk memberikan informasi terkait masalah amenitas di kawasan situs Sangiran.

Untuk memperoleh data yang valid, digunakan teknik pengumpulan data. Creswell (2016) menyatakan bahwa terdapat empat bentuk pengumpulan data dalam studi kasus yaitu: observasi, wawancara, dokumentasi, materi audio-visual. Adapun waktu pengumpulan data dilakukan dengan metode wawancara dan observasi. Teknik analisis data dan strategi validitas dilakukan 
dengan menggunakan metode triangulasi dengan memeriksa bukti-bukti yang berasal dari sumber tersebut dan menggunakannya untuk membangun justifikasi tema-tema secara koheran, menerapkan member checking untuk mengetahui akurasi hasil penelitian, membuat deskripsi yang kaya dan padat tentang hasil penelitian. Mengklarifikasi bias yang mungkin dibawa peneliti ke dalam penelitian, menyajikan informasi yang berbeda atau negatif yang dapat memberikan perlawanan pada tema-tema tertentu, memanfaatkan waktu yang relatif lama dilapangan atau lokasi penelitian, melakukan tanya-jawab dengan sesama rekan peneliti untuk meningkatkan ke akuratan hasil penelitian, mengajak seorang auditor untuk mereview keseluruhan proyek penelitian. Creswell (2016).

\section{Hasil dan pembahasan}

Hasil penelitian ini menunjukkan adanya kendala atau tantangan yang dihadapi oleh Pokdarwis Wonderful dalam mengembangkan kepariwisataan di Sangiran. Adapun kendala yang dihadapi Pokdarwis Wonderful dijelaskan dalam hasil penelitian ini seperti : isu konflik dalam organisasi Pokdarwis Wonderful Sangiran, rendahnya tingkat partisipasi masyarakat karena perbedaan persepsi , lemahnya komunikasi antar lembaga, pengelolaan organisasi kurang efektif, serta kurangnya inovasi dalam pengembangan produk-produk wisata.

\section{Isu Konflik dalam Organisasi Pokdarwis Wonderful Sangiran}

Kelompok Sadar Wisata (Pokdarwis) merupakan salah satu unsur yang dimaksud untuk menggerakkan kesadaran kepariwisataan dikalangan masyarakat yang berada dalam kawasan wisata atau objek wisata. Kehadirannya sebagai mitra dari stakeholder yang ada bertujuan untuk membantu pengembangan kepariwisataan yang dikelola secara swadaya oleh masyarakat. Dalam proses pembentukannya Pokdarwis Wonderful memiliki dua pendekatan, yakni :inisiatif masyarakat, dan inisiatif pemerintah. Terkait dengan pembentukan Pokdarwis Wonderful Sangiran digunakan pendekatan yang didasarkan atas inisiatif masyarakat.

Tabel 1. Isu konflik dalam organisasi Pokdarwis Wonderful Sangiran

\begin{tabular}{cl}
\hline No & \multicolumn{1}{c}{ Interpretasi } \\
\hline 1a & $\begin{array}{l}\text { Adanya komunitas atau organisasi lain yang juga bergerak untuk mengembangkan pariwisata di } \\
\text { Sangiran, yang dianggap oleh Pokdarwis Wonderful sebagai pesaing. }\end{array}$ \\
1b & $\begin{array}{l}\text { Anggota Pokdarwis tidak merasa harus bergabung ke Pokdarwis untuk mendapatkan penghasilan } \\
\text { (Artinya Pokdarwis dianggap sebagai ladang untuk mendapatkan penghasilan) }\end{array}$ \\
1c & Tidak ada keharusan untuk memasukkan setoran ke kas \\
1d & $\begin{array}{l}\text { Ada anggota Pokdarwis yang kemudian memisahkan diri dari Pokdarwis Wonderful dan } \\
\text { membentuk kelompok sendiri. }\end{array}$ \\
1e & $\begin{array}{l}\text { Pengurus Pokdarwis merasa ada sentimen pribadi masyarakat terhadap pengurus Pokdarwis } \\
\text { Wonderful. }\end{array}$ \\
1f & $\begin{array}{l}\text { Pengurus Pokdarwis merasa kurang diperhatikan oleh pemerintah lokal, pengelola museum, } \\
\text { maupun dinas terkait sehingga kegiatan yang diprogramkan tidak dapat dilaksanakan. }\end{array}$ \\
\hline
\end{tabular}

Sumber : diolah dari data lapangan

Rahim (2012) menyatakan tentang pendekatan yang digunakan untuk membentuk Pokdarwis didasarkan atas inisiatif masyarakat maka prosedur yang berlaku dengan melibatkan pihak pemerintah desa yang kemudian mengajukannya kepada pihak pemerintah daerah melalui dinas terkait. Skema pembentukan tersebut dimulai dari inisiatif masyarakat yang difasilitasi oleh pemerintah. Skema ini sifatnya mengusulkan dari bawah ke atas dengan dukungan dari aras lokal sebagai modal utama. Hal ini berbeda dengan pendekatan kedua yang secara prosedural digerakkan oleh pemerintah dengan menggalang dukungan dari masyarakat dalam kepentingan pengembangan pariwisata, sehingga akan menghasilkan proses dan dampak yang berbeda, begitu juga dengan tingkat partisipasi masyarakat.

Atas dasar inisiatif masyarakat akhirnya Pokdarwis Wonderful Sangiran dibentuk pada tanggal 6 November 2016 berdasarkan Surat Keputusan Kepala Dinas Pariwisata, Kebudayaan, 
Pemuda dan Olahraga Kabupaten Sragen dengan nomor 556/63/023/2016 tentang Pengukuhan Kelompok Sadar Wisata (Pokdarwis) "Wonderful Sangiran" Kabupaten Sragen. Dalam surat keputusan tersebut memuat ketentuan terkait dengan tugas dan fungsi Pokdarwis sebagai berikut: 1.Sebagai mitra kerja Dinas Pariwisata, Kebudayaan, Pemuda, dan Olahraga Kabupaten Sragen dalam kegiatan pemasaran pariwisata dan pengembangan kepariwisataan Kabupaten Sragen, teruatama di kawasan Sangiran. 2. Berperan aktif memelihara dan mengembangkan potensi pariwisata di Kabupaten Sragen terutama kawasan Sangiran Kabupaten Sragen. 3.Melaksanakan kegiatan keorganisasian yang mengedepankan kebersamaan, musyawarah mufakat, dan kesejahteraan masyarakat. 4.Mengimplementasikan Sapta Pesona dalam setiap kegiatan, dan menciptakan kondisi masyarakat kawasan Sangiran sebagai insan yang sadar wisata dengan menerapkan prinsip-prinsip Sapta Pesona.

Dengan memerhatikan dokumen pembentukan Pokdarwis Wonderful Sangiran adanya pengurus dan anggota yang berjumlah besar serta memiliki struktur yang lengkap dengan seksiseksi dan kordinator untuk setiap museum dan Anggaran Dasar/Anggaran Rumah Tangga (AD/ART) yang mengatur tentang keberadaan kelompok maka organisasi ini memiliki sumber daya manusia yang cukup. Dari komposisi yang tersedia dapat ditarik kesimpulan bahwa organisasi ini dapat berjalan secara efektif dengan dukungan dari masyarakat. Dunn (2003) menyatakan "upaya penguatan dan peningkatan kapasitas, peran dan inisiatif masyarakat sebagai salah satu pemangku kepentingan, untuk dapat berpartisipasi dan berperan aktif sebagai subjek atau pelaku maupun sebagai penerima manfaat dalam pengembangan kepariwisataan secara berkelanjutan"

Akan tetapi sekalipun proses pembentukan Pokdarwis Wonderful Sangiran berasal dari dukungan dan kesadaran masyarakat, nyata bahwa perjalananya tidak berbanding lurus dengan efektivitas kerja-kerja organisasi. Terdapat berbagai faktor yang menghambat Pokdarwis Wonderful Sangiran dalam menjalankan fungsi dan perannya seperti hasil wawancara dengan ketua Pokdarwis sebagai berikut :

"Organisasi Pokdarwis merupakan organisasi masyarakat yanng memiliki tanggung jawab untuk mengembangkan potensi wisata di daerah Sangiran. Salah satu masalah yang dihadapi Pokdarwis Sangiran mulai muncul organisasi dan komunitas lain yang tidak berafiliasi dengan Pokdarwis Sangiran seperti komunitas budaya, kelompok perajin dan kelompok home stay. Kemudian Kepala Desa memberikan kewenangan mengelola destinasi wisata baru di Punden Tingir kepada organisasi Forsa (Forum Remaja Sangiran) yang dari segi pemahaman dan kompetensi yang dimilik, kurang memahami kondisi dan sejarah Sangiran. Kelompok-kelompok ini dibentuk untuk menjadi rivalitas organisasi Pokdarwis Wonderful, sehingga masyarakat Sangiran kurang berkenan bergabung ke Pokdarwis Wonderful" S.S

Berdasarkan tabel 1, adanya perpecahan dan tingginya kecemburuan sosial di tataran anggota menjadi akar masalah yang dihadapai Pokdarwis Wonderful. Johnson (1990) mengemukakan bahwa konflik yang sengit dapat memicu perselisihan dan permusuhan yang tajam, yang mengganggu suasana antar kelompok dalam masyarakat.

Disamping itu keinginan masyarakat untuk mendapatkan manfaat ekonomi secara instan dengan kehadiran museum makin memperkeruh suasana dalam pengembangan kepariwisataan di Sangiran. Di satu sisi Pokdarwis Wonderful ingin lebih diperhatikan dan diberikan tugas dan wewenang lebih karena organisasi ini awalnya dipahami sebagai penjaga warisan budaya di Sangiran. Pemahaman ini muncul karena selama ini organisasi Pokdarwis Wonderful berkontribusi besar mendampingi para peneliti asing maupun lokal melakukan eskavasi fosil di Sangiran, sehingga otoritas sebagai penjaga warisan budaya selalu terpatri dalam tindakan dan kegiatan organisasi sehari-hari.

Hasil wawancara dengan pengurus organisasi Pokdarwis Wonderful menyatakan :

"Peran dan fungsi Pokdarwis kurang berdampak ke masyarakat Sangiran, karena kurangnya perhatian dan respons pemerintah desa, BPSMPS dan Dinas Pariwisata Kabupaten sehingga kegiatan-kegiatan dan program yang direncakan banyak tidak berjalan dan kendalanya dimasalah pendanaan atau pembiayan program. Contoh dalam pembentukan desa wisata Pokdarwis tidak 
dilibatkan. Padahal fungsi Pokdarwis itu sebagai kelompok sadar wisata dan penjaga nilai Situs Sangiran.". DM

Lanjut pengurus organisasi Pokdarwis Wonderful menyatakan:

"Pokdarwis Wonderful mengakui bahwa lemah di sumber daya masyarakat (sdm) sehingga terobosan-terobosan tentang pengembangan kepariwisataan mengalami hambatan disamping masalah pendanaan. Untuk pendanaan organisasi bersumber dari iuran anggota yang terlibat di jasa guiding. Kemudian anggota Pokdarwis banyak yang keluar dari organisasi ini, disebabkan adanya perpecahan dengan teman-teman pemandu (guiding). Mereka lebih memilih membentuk komunitas sendiri. Adapun alasan mereka, tanpa bergabung ke Pokdarwis Wonderful juga dapat penghasilan, dan tidak harus menyetor ke kas. Dari sini awal perpecahan anggota Pokdarwis Wonderful sehingga mereka membentuk komunitas sendiri". DM

Selain itu, dendam pribadi ke ketua Pokdarwis Wonderful juga memengaruhi sebagaimana disampaikan oleh pengurus Pokdarwis klaster Bukuran :

"Selanjutnya adanya rasa dendam pribadi masyarakat dan kepala desa kepada ketua Pokdarwis Wonderful berimbas kepada semua anggota organisasi Pokdarwis sehingga terhambat program-program yang direncanakan". MK

Perbedaan motif dari ekspresi kepentingan tersebut kemudian menimbulkan masalah yang kompleks dan sulit diselesaikan. Harapannya pihak-pihak terkait dan Pokdarwis Wonderful bersama-sama menjalankan peran dan fungsinya dalam pengembangan kepariwisataan di Sangiran. Dengan masalah yang dihadapi Pokdarwis Wonderful, saat ini mereka tetap menjalankan program yang selama ini dilakukan di museum manusia purba seperti pekerjaan jasa guiding maupun eskavasi yang menjadi salah satu sumber penghasilan yang menopang pendanaan organisasi Pokdarwis Wonderful.

Minimnya partisipasi masyarakat yang bergabung dalam organisasi Pokdarwis Wonderful Sangiran menjadi salah satu faktor penyebab kurang berdampaknya dalam pengembangan wisata di Sangiran. Ditambah ketidak mampuan pengurus dalam menyelesaikan masalah menjadi alasan mengapa masyarakat Sangiran kurang tertarik bergabung dengan organisasi ini. Disamping itu komunikasi dan koordinasi dengan lembaga-lembaga seperti Pemerintah Desa, BPSMPS dan Dinas Pariwisata Pemuda, Olahraga dan Kebudayaan Kabupaten Sragen kurang berjalan secara optimal sehingga memperumit masalah yang dihadapi Pokdarwis Wonderful. Padahal lembagalembaga tersebut diharapkan mampu sebagai strategis yang mengusahakan secara kolektif hak dan kepentingan masyarakat Sangiran terkhusus dalam pengembangan kepariwisataan.

Masyarakat yang selama ini telah terkungkung dalam persepsinya sendiri mengakibatakan rendahnya tingkat partisipasi yang bergabung ke organisasi Pokdarwis Wonderful. Perbedaan persepsi tentang pengelolaan pariwisata di situs manusia purba Sangiran harus direkonstruksi terlebih dahulu supaya persepsi yang baru dapat diterima dengan baik dan selaras dengan visi dan misi organisasi. Dibutuhkan seorang tokoh sebagai mediator tanpa memihak kepada siapa pun dalam menyelesaikan masalah. Kehadiran mediator tersebut harus mampu diterima berbagai kelompok serta mampu mengakomodir harapan serta adil dalam menyelesaikan masalahmasalah yang selama ini terjadi.

\section{Rendahnya Tingkat Partisipasi Masyarakat Karena Perbedaan Persepsi.}

Persoalan utama yang dihadapi oleh Pokdarwis Wonderful Sangiran adalah minimnya tingkat partisipasi masyarakat dan tidak aktifnya sejumlah anggota organisasi. Dari 64 anggota yang aktif hanya tersisa 30 orang. Bahkan tidak mengalami kenaikan secara signifikan dalam hal rekruitmen anggota. Berdasarkan data terakhir dari partisipasi masyarakat dalam pelatihan hanya terdapat 13 orang saja. Minimnya tingkat partisipasi masyarakat dipengaruhi oleh alasan dampak ekonomi. Masyarakat lebih memilih bekerja secara mandiri dari pada bergabung dalam organisasi yang dirasakan tidak memiliki dampak secara ekonomis. Hal ini memang bukan hal yang baru di dalam masyarakat di kawasan Sangiran. Persepsi masyarakat tentang kawasan situs Sangiran dan museum manusia purba kuat dipengaruhi oleh faktor ekonomi dari pada merawat kawasan Sangiran. 
Tabel 2. Penyebab rendahnya tingkat partisipasi masyarakat karena perbedaan persepsi.

\begin{tabular}{ll}
\hline No & \multicolumn{1}{c}{ Interpretasi } \\
\hline 2a & Masyarakat lokal Sangiran yang berada di luar lingkaran museum mereka tidak peduli untuk \\
& pariwisatanya karena mereka tidak terdampak langsung, dan lebih tertarik ke penemuan fosil yang \\
& memiliki nilai ekonomi. \\
2b & $\begin{array}{l}\text { Organisasi Pokdarwis berorientasi ke program sosial dan profitnya kurang, sehingga masyarakat } \\
\text { lebih fokus untuk pekerjaan utamanya }\end{array}$ \\
2c & $\begin{array}{l}\text { Setiap anggota Pokdarwis harus memiliki wawasan dan pengalaman tentang kawasan situs } \\
\text { Sangiran }\end{array}$ \\
\hline
\end{tabular}

Sumber : Diolah dari penelitian lapangan

Hasil olahan data di lapangan dapat dilihat dalam hasil wawancara. Seperti wawancara yang dilakukan dengan staff Badan Pelestarian Situs Manusia Purba Sangiran (BPSMPS) menyatakan sebagai berikut :

"Berbicara tentang Sangiran orang dan wisatawan kagum akan potensi yang ada di Sangiran. Tapi masyarakat sekitar justru tidak pernah datang ke Museum. Kemudian Orang yang berada di luar lingkaran museum mereka tidak peduli untuk parawisatanya karena mereka tidak terdampak langsung.Tetapi masyarakat lebih tertarik ke penemuan fosil. Kalau bicara ke masyarakat pasti ujung-ujungnya ekonomi, dan manfaat ekonomi yang mereka dapat. MD

Jika ditelisik lebih jauh akar permasalahannya terdapat pada perbedaan persepsi yang berkembang pada masyarakat di kawasan Sangiran. Persepsi masyarakat di kawasan situs Sangiran pada umumnya telah dibentuk dengan manfaat ekonomi ( Tabel 2). Wujud nyata kehadiran Pokdarwis dilihat dalam bingkai ekonomi semata. Ketika kehadiran Pokdarwis tidak memberikan dampak ekonomi yang dirasakan oleh masyarakat, maka pilihan untuk bekerja menjadi pilihan yang rasional. Sastropoetro (1988) menyatakan faktor-faktor yang memengaruhi partisipasi masyarakat dalam pembangunan adalah pendidikan, kemampuan membaca dan menulis, kemiskinan, kedudukan sosial dan percaya terhadap diri sendiri, interpretasi yang dangkal terhadap agama, kecenderungan untuk menyalah artikan motivasi, tujuan dan kepentingan organisasi penduduk yang biasanya mengarah kepada timbulnya persepsi yang salah terhadap keinginan dan motivasi serta organisasi penduduk seperti halnya terjadi di beberapa negara dan tidak terdapatnya kesempatan untuk berpartisipasi dalam berbagai program pembangunan.

Senada dengan itu Dinas Pariwisata, Pemuda, Olahraga dan Kebudayaan Kabupaten Sragen juga mengakui faktor kurangnya partisipasi masyarakat dilatar belakangi motif ekonomi seperti dalam hasil wawancara sebagai berikut :

"Kurangnya minat masyarakat bergabung ke organisasi Pokdarwis Wonderful karena organisasi ini berorientasi ke program sosial dan profitnya kurang, sehingga masyarakat lebih fokus untuk pekerjaan utamanya, atau untuk mencari biaya hidup seperti petani dan lain sebagainya. Kemudian Adanya konflik pribadi yang berakar dari kepentingan anggota seperti masalah ekonomi di Sangiran." I $H$

Kesadaran seperti ini bukanlah hal yang baru tumbuh didalam masyarakat, sejarah panjang menunjukkan bahwa masyarakat Sangiran telah mengalami perubahan kesadaran dari religiusmagis kedalam kesadaran ekonomi sejak dilakukannya eskavasi dan penelitian oleh para peneliti asing. Para peneliti asing menetapkan sistem upah untuk menghargai setiap temuan dari proses eskavasi yang ditemukan oleh masyarakat pada saat itu, seperti hasil riset Sulistyanto (2009) menjelaskan :

"pada era Von Koenigswald, antara tahun 1930-1940 merupakan tahun-tahun mendasar bagi perubahan sikap dan perilaku penduduk Sangiran dalam memaknai warisan budaya di sekitarnya. Kedatangan Von Koenigswald dan rombongan para peneliti asing di Sangiran dalam kenyataannya membawa dampak pergeseran keyakinan, yaitu dari nilai religius-magis ke nilai ekonomis. Anak-anak pada generasi ini telah mengalami sosialisasi berorientasi ekonomi sehingga berpikir bahwa fosil identik dengan uang. Dengan demikian, Von Koenigswald dan ilmuwan lain 
pada waktu itulah yang sebenarnya dapat dikatakan "meletakkan dasar" terjadinya perubahan sikap dan perilaku penduduk di dalam memaknai warisan budaya Sangiran hal. 64".

Persepsi masyarakat juga dapat dilihat dari para pelaku usaha kuliner yang memilih untuk membuka usaha secara mandiri di luar kawasan museum Sangiran. Hasil wawancara dengan pengusaha kuliner di sekitar Museum Krikilan menyatakan :"setiap anggota Pokdarwis harus memiliki wawasan dan pengalaman tentang kawasan situs Sangiran". M T

Syarat-syarat tersebut dirasa sulit untuk dipenuhi oleh masyarakat lokal. Adanya penafsiran berbeda dengan kehadiran organisasi Pokdarwis Wonderful menambah daftar panjang rendahnya keterlibatan masyarakat lokal bergabung ke organisasi Pokdarwis Wonderful. Masyarakat merasa bahwa tanpa bergabung dengan Pokdarwis Wonderful juga tetap mendapatkan hasil dari museum seperti jasa guding, suvenir pengelola homestay dan mereka lebih mandiri dari pada bergabung ke organisasi Pokdarwis Wonderful.

Sementara itu, melihat hakekat kehadiran organisasi Pokdarwis Wonderful lebih di tekankan pada pengembangan SDM masyarakat. Rahim (2012) menjelaskan bahwa Pokdarwis merupakan kelompok swadaya dan swakarsa masyarakat yang dalam aktivitas sosialnya berupaya untuk: Meningkatkan pemahaman kepariwisataan, meningkatkan peran dan partisipasi masyarakat dalam pembangunan kepariwisataan, meningkatkan nilai manfaat kepariwisataan bagi masyarakat/anggota Pokdarwis, menyukseskan pembangunan kepariwisataan.

Untuk itu diharapkan organisasi Pokdarwis Wonderful kembali memetakan potensipotensi lokal untuk dikembangkan sebagai program unggulan dalam pengembangan kepariwisataan di Sangiran. Kemudian perlu adanya kesadaran bersama yang selama ini berbeda yang dimana bertujuan untuk merawat kawasan Sangiran sehingga ke depan semua perencanaan pengembangan kepariwisataan di Sangiran dapat berjalan bersama.

\section{Lemahnya komunikasi antar lembaga}

Pokdarwis Wonderful menjadi aktor utama dalam membangun konsep sadar wisata kepada masyarakat lokal di kawasan Sangiran. Rahim (2012) menyatakan Pokdarwis sebagai bentuk kelembagaan informal yang dibentuk anggota masyarakat (khususnya yang memiliki kepedulian dalam mengembangkan kepariwisataan di daerahnya), merupakan salah satu unsur pemangku kepentingan dalam masyarakat yang memilki keterkaitan dan peran penting dalam mengembangkan dan mewujudkan sadar wisata dan Sapta Pesona di daerahnya.

Tabel 3. Lemahnya komunikasi antar lembaga

\begin{tabular}{ll}
\hline No & \multicolumn{1}{c}{ Interpretasi } \\
\hline 3a & Tidak efektifnya organisasi Pokdarwis disebabkan komunikasi yang kurang baik antara kepala \\
& desa dengan Pengurus Pokdarwis Wonderful. \\
3b & $\begin{array}{l}\text { Legalitas SK Pokdarwis Wonderful tidak diterbitkan dari Desa Krikilan. Pengangkatan SK } \\
\text { Pokdarwis Wonderful di terbitkan oleh Dinas Pariwisata Kabupaten Sragen mencakup 5 klaster }\end{array}$ \\
& $\begin{array}{l}\text { yang berada di kawasan Sangiran, sehingga mempengaruhi komunikasi Pokdarwis Wonderful } \\
\text { dengan pemerintahan desa di kawasan Sangiran, }\end{array}$ \\
3c & $\begin{array}{l}\text { Upaya yang telah di lakukan Pokdarwis Wonderful Sangiran mengundang 4 (empat) kepala desa } \\
\text { untuk duduk bersama membicarakan permasalahan di Sangiran ini, tapi mereka tidak ada respons } \\
\text { sama sekali }\end{array}$ \\
\hline
\end{tabular}

Sumber : Diolah dari penelitian lapangan

Hasil olahan data di lapangan dapat dilihat dalam wawancara yang dilakukan dengan ketua Pokdarwis Wonderful :

"Saat ini faktor penyebab ketidak efektifan organisasi Pokdarwis disebabkan komunikasi yang kurang baik antara kepala desa dengan Pengurus Pokdarwis Wonderful Sangiran serta mereka selalu katakan belum ada kerja sama yang baik, kurang komunikasi terkadang itu bahasa yang selalu digunakan. "S.S

Kurangnya memaknai fungsi organisasi menjadi kendala yang dihadapi Pokdarwis Wonderful (Tabel 3). Di sini sangat jelas letak masalahnya tidak terbukanya ruang kerja sama antar lembaga. Memang jelas dikatakan bahwa organisasi Pokdarwis Wonderful dari segi 
legalitasnya di terbitkan Dinas Pariwisata, Kebudayaan, Pemuda dan Olahraga Kab. Sragen yang mencakup seluruh kawasan Sangiran. Padahal fokus kerja Pokdarwis Wonderful hanya terpaku dalam 1 museum center Krikilan saja, dan perlu adanya upaya mengelola potensi wisata di 4 klaster museum.

Menanggapi hal tersebut, wawancara yang dilakukan dengan kepala Desa Krikilan yaitu :

"Kurangnya kebersamaan menjadi masalah yang di hadapi organisasi Pokdarwis. Saat ini organisasi Pokdarwis wonderful kurang berkembang karena adanya perpecahan di tubuh organisasi Pokdarwis wonderful dan tidak mampu duduk bersama menyelesaikan masalah. Adanya perbedaan pemahaman tentang Sangiran dan bidang pekerjaan di sekitar museum menghantarkan konflik internal pokdariwis berlanjut salah satunya penggunaan jasa Guide. Bidang jasa Guide merupakan bagian dari organisasi Pokdarwis Wonderful. Kemudian bahwa masalah internal Pokdarwis tidak dapat di selesaikan pemerintah desa, karena legalitas SK Pokdarwis Wonderful tidak dari Desa Krikilan. Pengangkatan SK Pokdarwis wonderful di terbitkan oleh Dinas Pariwisata Kabupaten Sragen mencakup 5 klaster yang berada di kawasan konservasi Kabupaten Sragen". P W

Sementara potensi yang berada di wilayah kerja desa lainnya belum maksimal dilakukan oleh Pokdarwis. Memang ada beberapa kendala seperti kekurangan amenitas dan fasilitas di 4 museum klaster, salah satunya adalah akses jalan (infrastruktur) yang kurang memadai. Saat ini kondisi menuju akses ke 4 klaster Museum kurang bagus untuk di lalui kendaraan roda empat seperti banyaknya jalan banyak yang rusak, ditambah lebar jalan hanya bisa dilalui 1 mobil.

Melihat fenomena tersebut, pengurus Pokdarwis Wonderful berupaya untuk mengundang para kepala desa di kawasan Sangiran untuk berbicara tentang pengembangan wisata. Namun niat tersebut kurang direspons dengan baik, seperti hasil wawancara yang dilakukan dengan pengurus klaster Pokdarwis Wonderful yaitu:

"Kami sadar bahwa pengembangan wisata di Sangiran ini masih sangat kurang, kami berharap perlunya kerja sama antara antara semua pihak untuk duduk bersama membicarakan, bagaimana cara pengembangan wisata di Sangiran supaya lebih baik. Adapun upaya kami untuk mengundang dari pihak 4 (empat) kepala desa untuk duduk bersama untuk membicarakan permasalahan di Sangiran ini, tapi mereka tidak ada respons sama sekali". MD

Oleh karena itu untuk menerobos kebekuan-kebekuan yang membatasi kerja sama antar pemangku kepentingan dan masyarakat lokal, maka ke dua lembaga harus membuka ruang diskursus yang lebih serius dalam perencanaan dan implementasi pengembangan destinasi pariwisata maupun atraksi wisata. Harapanya dengan kehadiran lembaga pemerintah dan Pokdarwis Wonderful bukan dalam rangka persaingan melainkan sebagai mitra yang memiliki tujuan yang sama.

\section{Pengelolaan organisasi kurang efektif}

Organisasi Pokdarwis Wonderful dapat dengan leluasa bergerak ketika pembagian tugas dapat diperinci secara detail dalam pengembangan wisata di Sangiran. Rahim (2012) menyatakan sadar wisata dalam hal ini di gambarkan sebagai bentuk kesadaran masyarakat untuk berperan aktif dalam 2 hal yaitu: Masyarakat menyadari peran dan tanggung jawabnya sebagai tuan rumah (host) yang baik bagi tamu atau wisatawan yang berkunjung untuk mewujudkan lingkungan dan suasana yang kondusif sebagaimana tertuang dalam slogan Sapta Pesona, kedua masyarakat menyadari hak dan kebutuhannya untuk menjadi pelaku wisata atau wisatawan untuk melakukan perjalanan ke suatu daerah tujuan wisata, sebagai wujud kebutuhan dasar untuk berekreasi maupun khususnya dalam mengenal dan mencintai tanah air.

Tabel 4. Pengelolaan organisasi kurang efektif

\begin{tabular}{ll}
\hline No & \multicolumn{1}{c}{ Interprestasi } \\
\hline 4a & $\begin{array}{l}\text { Komunikasi Organisasi Pokdarwis dengan masyarakat Sangiran sangat kurang dan bahkan tidak } \\
\text { berjalan sama sekali, sehingga mempengaruhi kaderisasi yang bermuara kepada pengelolaan } \\
\text { organisasi. }\end{array}$ \\
4b & $\begin{array}{l}\text { Kemudian salah satu faktor masyarakat kurang berminat bergabung ke Pokdarwis karena tipikal } \\
\text { dan kapasitas pemimpinnya kurang cepat mengurus kebutuhan organisasi. }\end{array}$
\end{tabular}


4c Kemudian kurangnya kegiatan yang dilakukan oleh Pokdarwis sehingga masyarakat kurang berminat bergabung.

4d Adanya kekosongan peran pembimbing / pembina organisasi Pokdarwis. Fungsi pembimbing dan sebagai mentor diharapkan mampu membimbing pengurus dalam mengelola organisasi

4e Pada hakekatnya Pokdarwis Wonderful Sangiran sendiri yang kurang memanfaatkan potensi yang ada di Sangiran.

4f Kehadiran Pokdarwis Wonderful diharapkan mampu merubah mindset (mindset) masyarakat untuk lebih memahami dan mencintai museum supaya berdaya guna untuk kehidupan masyarakat Sangiran. Hal ini merupakan tugas dan pengelolaan organisasi Pokdarwis Wonderful.

$4 \mathrm{~g}$ Pelatihan itu sudah banyak BPSMS berikan tetapi tidak ada kemajuan dan perkembangan. Mereka sudah banyak dibimbing dan dilatih ternyata mereka kurang keseriusan mengimplementasikan hasil pelatihan-pelatihan yang sudah di berikan.

Sumber : Diolah dari penelitian lapangan

Akan tetapi tidak aktifnya sejumlah pengurus telah menyebabkan beberapa fungsi dan peranan organisasi tidak berjalan secara efektif. Hal ini dipengaruhi tidak berjalannya fungsi pembinaan dalam struktur organisasi. Akibat minimnya pembinaan berpengaruh besar dalam perjalanan organisasi Pokdarwis Wonderful.

Masalah lainnya yang mendera organisasi ini berkisar pada masalah kepemimpinan yang dinilai lamban dalam memenuhi kebutuhan organisasi dan kurangnya transparansi dalam mengelola organisasi (Tabel 4). Hal ini kemudian menyebabkan salah satu inisiator yang membentuk Pokdarwis Wonderful Sangiran mengundurkan diri dan mengembangkan usaha jasa guiding secara mandiri. Sebagian anggota Pokdarwis yang semula menjalankan usaha guiding dalam naungan Pokdarwis Wonderful memilih keluar dan bergabung ke salah satu inisiator yang mengundurkan diri. Menyikapi itu ditemukan fakta-fakta bahwa pola menejemen organisasi Pokdarwis Wonderful dalam pengembangan kepariwisataan sangat kurang efektif. Hal ini bisa di lihat dari wawancara yang dilakukan kepada salah satu pendiri Pokdarwis yang memilih keluar:

"Komunikasi Organisasi Podarwis dengan masyarakat Sangiran sangat kurang dan bahkan tidak berjalan sama sekali. Bahkan, organisasi Pokdarwis Wonderful ini tidak berafiliasi dengan Kepala Desa Krikilan. Kemudian salah satu faktor masyarakat kurang berminat bergabung ke Pokdarwis karena tipikal dan kapasitas pemimpinnya kurang cepat mengurus kebutuhan organisasi. Kemudian kurangnya kegiatan yang dilakukan oleh Pokdarwis sehingga masyarakat kurang berminat bergabung. Faktor selanjutnya fungsi dan peran pembimbing organisasi Pokdarwis tidak tersedia, padahal peranan pembimbing diharapkan sebagai mentor membawa keberhasilan organisasi Pokdarwis wonderful". PT

Dalam pengelolaan organisasinya, Pokdarwis Wonderful Sangiran belum sepenuhnya direncanakan secara matang. Kerja organisasi masih bertumpu pada ketua (pimpinan) dan hanya melakukan kegiatan rutinitas dan spontanitas tanpa diputuskan dalam rapat pengurus. Kegiatan yang dilakukan masih seputar peringatan hari warisan situs dunia, pelatihan guiding dan sosialisasi ke sekolah-sekolah. Kelemahan Pokdarwis Wonderful Sangiran belum memiliki program tahunan secara kontinu dan terintegrasi dengan fungsi pelaksanaan dan kerja sama dengan mitra maupun lembaga pemerintah. Hal ini senada dengan wawancara yang dilakukan dengan pihak BPSMPS menyatakan bahwa:

"Pemerintahan Kabupaten Sragen dan Pokdarwis harus mampu mengembangkan ide -ide dengan menawarkan paket wisata via online seperti atraksi wisata untuk dikembangkan dalam kesenian tradisional Sangiran. Kemudian strategi mendatangkan wisatawan di Sangiran, para wisatawan dapat merasakan sensasi mencari bukur (kerang) di saluran bapang. Selain itu, wisata juga bisa mengunjungi nano museum yang menawarkan sensasi eskavasi atau penggalian fosil-fosil yang ditemukan. Pada hakekatnya Pokdarwis Wonderful Sangiran sendiri yang kurang memanfaatkan potensi yang ada di Sangiran". MD

Selain itu, masalah pendanaan yang menopang eksistensi Pokdarwis Wonderful Sangiran belum dapat mandiri secara finansial. Sekalipun organisasi ini sifatnya swadaya, namun keterbatasan dan kemampuan anggota dalam menopang aktivitas organisasi sangat berpengaruh pada implementasi program dan kegiatan yang telah direncanakan. Untuk itu, kehadiran 
pemerintah sangat diharapkan membantu organisasi Pokdarwis Wonderful mencari solusi guna keberkanjutan organisasi.

Dalam perjalanan sejarah dan pembangunan museum di Sangiran, sering kali masyarakat Sangiran beranggapan bahwa BPSMPS memiliki dana untuk diberikan ke masyarakat Sangian. Pola pemikiran seperti ini menghantarkan rasa kecurigaan mendalam sehingga konsep dan pengembangan wisata di Sangiran tidak berjalan sama sekali. Hal ini sesuai dengan hasil wawancara yang dilakukan dengan Kepala Desa Krililan:

"Sejarahanya berawal dari masyarakat Sangiran yang memahami Musuem Manusia Purba dapat memberikan manfaat ekonomi ke masyarakat. Kebiasaan masyarakat Sangiran menuntut museum (BPSMSP) yang di mana pengelola Museum dapat memberikan penghasilan ke masyarakat. Kemudian kepala Desa berharap perlu upaya edukasi dan disadarkan dengan mengubah pola pikir (mindset) masyarakat untuk lebih memahami dan mencintai museum supaya berdaya guna untuk kehidupan masyarakat Sangiran. P W.

Senada dengan itu, pihak BPSMPS juga memberikan gambaran dan pola pikir masyarakat Sangiran dalam wawancara sebagai berikut:

"BPSMPS sering diskusi dengan Kepala Desa Krikilan terkait pengembangan potensi wisata Sangiran. Kepala Desa Krikilan merasakan beberapa hal yang kami lihat terkait pengembangan wisata Sangiran. Pelatihan itu sudah banyak BPSMS berikan tetapi tidak ada kemajuan dan perkembangan. Jika modal menjadi masalah, sesuai tupoksi BPSMPS modal bukan kewenangan BPSMSPS. Mereka sudah banyak dibimbing dan dilatih ternyata mereka kurang keseriusan mengimplementasikan hasil pelatihan-pelatihan yang sudah di berikan". MD

Dari beberapa fakta ini perlu diperkuat organisasi Pokdarwis Wonderful di Sangiran sebagai organisasi masyarakat yang menaungi kepariwisataan di Sangiran. Memang selama ini bahwa organisasi Pokdarwis Wonderful lebih fokus pada jasa guiding dan membantu BPSMPS maupun peneliti yang ingin melakukan eskavasi fosil. Jika di lihat dari tugas dan fungsi Pokdarwis Wonderful saat ini, sangat jauh dari tujuan organisasi Pokdarwis yang ditetapkan Kementrian Pariwisata. Untuk mencapai organisasi yang mapan, dibutuhkan strategi serta partisipasi masyarakat secara kolektif. Craig dan May, (1995) dalam Hikmat, (2004) menyatakan bahwa partisipasi merupakan komponen penting dalam pembangkitan kemadirian dan proses pemberdayaan. Lebih lanjut Hikmat (2004) menjelaskan pemberdayaan dan partisipasi merupakan strategi yang sangat potensial dalam rangka meningkatkan ekonomi, sosial dan transformasi budaya. Proses ini, pada akhirnya akan dapat menciptakan pembangunan yang berpusat pada rakyat.

Demikian juga dengan penerapan sadar wisata apabila dipadukan dengan struktur pengurus Pokdarwis Wonderful Sangiran dengan adanya seksi-seksi yang meliputi : hubungan masyarakat dan keamanan, promosi, homestay, kuliner, kerajinan dan suvenir, batik, guide, seni budaya dan kordinator unit untuk Kluster Bukuran, Kluster Manyarejo, Kluster Krikilan dan Kluster Ngebung akan menghasilkan dampak yang positif bagi masyarakat sebagai penerima manfaat. Sehingga pengelolaan organisasi Pokdarwis dapat terintegrasikan dengan model pengembangan berbasis masyarakat di Sangiran.

Namun tidak dapat dipungkiri disamping kapasitas pengurus yang terbatas, masalah pendanaan organisasi juga masalah yang paling vital. Kemampuan menejerial pengurus Pokdarwis mengusahakan pendanaan organisasi saat ini yang hanya bersumber dari iuran anggota kurang cukup untuk membiayai organisasi Pokdarwis. Dibutuhkan terobosan-terobosan baru dan keaktifan pengurus untuk menciptakan program-program yang mampu mendatangkan wisatawan ke Sangiran.

Pada model pengembangan dan pemberdayaan masyarakat lebih diarahkan prinsip kolektif dan kolaboratif pengurus sesama Pokdarwis Wonderful. Setelah persepsi menyatu, dibutuhkan perencanaan yang matang dengan pembagian tugas fungsi yang detail, sehingga tidak menimbulkan tumpang tindih pembagian fungsi dan peran dalam pembagian tugas di dalam organisasi. Jika kedua hal tersebut telah dirancang maka organisasi sudah mampu keluar dan berkolaborasi dengan lembaga dan kerja sama lintas sektoral. 


\section{Kurangnya inovasi dalam pengembangan produk-produk wisata}

Kurangnya inovasi dalam pengembangan kepariwisataan di Sangiran menunjukkan rendahnya kemampuan pengurus dalam pengembangan pariwisata di Sangiran. Organisasi Pokdarwis harus mampu menerjemahkan konsep sadar wisata dalam bentuk inovasi dan kreativitas dengan melihat potensi yang ada di kawasan Sangiran. Minimnya rapat dan kurang tersedianya wadah dalam menyampaikan gagasan dan ide program menghantarkan dinamika yang tidak sehat sehingga pengembangan produk-produk pengembangan wisata tidak berjalan sama sekali.

Tabel 5. Masalah kurangnya inovasi dalam pengembangan produk wisata

\begin{tabular}{ll}
\hline No & \multicolumn{1}{c}{ Interpretasi } \\
\hline $5 a$ & $\begin{array}{l}\text { Pokdarwis Wonderful belum mampu melakukan terobosan dan inovasi pengembangan wisata } \\
\text { di Sangiran. Pengelolaan yang dilakukan Pokdarwis Wonderful hanya di bidang jasa guading, } \\
\text { dan pengelolaan parkir }\end{array}$ \\
$5 \mathrm{~b}$ & $\begin{array}{l}\text { Rendahnya inovasi yang dilakukan Pokdarwis Wonderful berdampak pada suvenir yang } \\
\text { dipasarkan di museum itu bukan hasil dari buatan daerah Sangiran tetapi dari daerah lainnya } \\
\text { seperti daerah Solo }\end{array}$ \\
\hline Sumber: Diolah dari penelitian lapangan
\end{tabular}

Adanya ruang kosong ini mengakibatkan Pokdarwis Wonderful hanya melirik segmentasi museum di Sangiran. Begitu juga dengan komunitas lainnya yang berada di Sangiran kurang berkontribusi dalam menularkan inovasi dan kreativitas. Hal ini sesuai dengan hasil wawancara dengan pihak BPSMPS yang menyatakan bahwa:

"Mereka harus mengembangkan kulinernya harus kasih experiencenya dan tidak pernah berusaha mengembangkan bidang-bidang pariwisata di sini seperti kuliner, home stay, supaya pengunjaung long stay di Sangiran.". MD

Dalam pembangunan kepariwisataan diharapkan mampu untuk meningkatkan kesejahteraan masyarakat khususnya yang berdomisili di daerah kawasan tersebut. Murphy (1988) menyatakan pembangunan kepariwisataan tidak lepas dari sumber daya dan keunikan komunitas lokal, baik berupa elemen fisik maupun non fisik (tradisi dan budaya), yang merupakan unsur penggerak utama kegiatan wisata itu sendiri sehingga kepariwisataan dipandang sebagai kegiatan yang berbasis pada komunitas setempat.

Sementara pihak pemerintah desa Krikilan sendiri memiliki visi pengembangan desa wisata dengan tujuan agar memberikan dampak ekonomi bagi masyarakat Krikilan. Menurut pihak desa pengembangan dan pengelolaan wisata di kawasan Sangiran saat ini hanya menguntungkan segelintir pihak saja, seperti hasil wawancara dengan Kepala Desa: "Yang dipasarkan di museum itu bukan hasil dari buatan daerah Sangiran. Mungkin yang dijual disitu dari daerah Solo, jadi tidak ada kerja sama yang baik. " $P W$

Untuk itu, Pokdarwis Wonderful harus dapat menggali kekayaan lokal untuk dikelola bersama dengan masyarakat lokal untuk mampu mengangkat nilai-nilai kebudayaan yang nantinya ditawarkan kepada pengunjung. Dengan inovasi ini, corak pariwisata di Sangiran akan menawarkan atraksi budaya dan wisata edukasi yang mampu di kemas dalam pengembangan kepariwisataan di Sangiran.

Hasil penelitian Rara Sugiarti et al (2019) menggambarkan relasi kelembagaan dalam kaitannya dalam upaya pengembangan wisata. Berkaitan dengan pengembangan Sangiran sebagai kawasan wisata, Pemprov dan Pemkab terlibat langsung dalam menyediakan fasilitas dan pemberdayaan masyarakat. Meskipun demikian, dalam beberapa hal, kewenangan masingmasing saling beririsan sehingga seringkali terkesan tumpang tindih. Bahkan, hingga saat ini Kabupaten Sragen belum memiliki dokumen RIPDA/RIPKA sebagai acuan pengembangan pariwisata di kabupaten Sragen.

Kontribusi swasta dalam mendukung upaya revitalisasi kawasan Sangiran melalui pendidikan dan pariwisata masih sangat terbatas. Seperti diakui oleh BPSMP Sangiran selaku pengelola Museum Sangiran, hingga saat ini swasta belum mampu secara nyata memberi 
kontribusi bagi revitalisasi Sangiran. Hal diduga disebabkan karena Sangiran merupakan kawasan yang dilindungi secara ketat di bawah pengawasan UNESCO sehingga tidak mudah bagi pihak lain turut mengelola Sangiran.

Mengacu penelitian di atas menggambarkan bahwa keberadaan kawasan pariwisata di Sangiran tidak terlepas dari dukungan dan kewenangan pemerintah daerah dan pusat. Adapun kewenangan pemerintah Kabupaten Sragen yaitu pengelolan parkir dan retribusi daerah. Sedangkan infrastruktur jalan berada dalam kewenangan Pemerintah Provinsi Jawa Tengah dan pengelolaan museum manusia purba ( BPSMPS) dikelola oleh UPT Kementerian Pendidikan dan Kebudayaan di bidang pelestarian manusia purba.

Saat ini tantangan yang dihadapi oleh Pokdarwis Wonderful kurangnya dukungan dalam pengembangan pariwisata di Sangiran. Seperti contoh : akses jalan yang rusak harus mendapat persetujuan pemerintah Provinsi. Begitu juga dengan pembangunan pemukiman di kawasan konservasi Sangiran, yang dimana harus mendapat persetujuan lembaga terkait. Kemudian munculnya persepsi masyarakat lokal yang dimana adanya dugaan dan kecurigaan dengan kehadiran BPSMPS mampu memberikan "uang" ke masyarakat lokal. Hal ini merupakan tugas organisasi Pokdarwis Wonderful sebagai mitra kelembagaan sebagai jembatan dan komunikator ke masyarakat untuk mampu memberikan pemahaman ke masyarakat lokal akan tugas dan fungsi lembaga pemerintah yang berada di kawasan Sangiran.

Penguatan kapasitas sumber daya manusia (sdm) organisasi Pokdarwis Wonderful merupakan hal yang substansi dalam proses perjalanan organisasi. Sangat aneh rasanya bilamana proses kaderisasi tidak berjalan dengan baik. Hal yang utama ditingkatkan adalah tersedianya anggota/ kader dan membangun komitmen bersama dalam visi organisasi ke depan. Saat ini adanya penafsiran berbeda dan tujuan organisasi Pokdarwis, mereduksi kepercayaan anggota yang hendak bergabung ke Pokdarwis Wonderful. Belum lagi meningkatnya rasa kecemburuan sesama pengurus dan ke anggota yang mempengaruhi kinerja organisasi dalam pengembangan wisata di Sangiran. Dengan demikian, hal yang perlu di upayakan adalah terbentuknya sistim menejemen organisasi Pokdarwis Wonderful.

Hasil penelitian Djumiarti (2020) memberikan masukan dan saran tentang keberlanjutan organisasi Pokdarwis Wonderful Sangiran dengan menjalankan visi misi dan tujuan sebagai landasan nyata yang sesuai dengan kepentingan umum; status resmi; struktur organisasi yang menitikberatkan pada komitmen tujuan organisasi. Dalam hal ini, kader dan pengurus Pokdarwis Wonderful Sangiran diarahkan mengedepankan nilai-nilai demokrasi dalam pengambilan keputusan yang berlandaskan kepercayaan, hukum, dan responsivitas. Dari segi kualitas pelaksanaan akuntabilitas, Pokdarwis Wonderful Sangiran masih perlu ditingkatkan agar berorintasi pada prinsip akuntabilitas. Strategi ini diharapkan untuk menciptakan profil kader Pokdarwis Wonderful dengan nilai-nilai integritas sehingga kehadiran Pokdarwis Wonderful dapat diterima masyarakat dan Pemerintah.

\section{1) Meningkatkan Partisipasi Masyarakat}

Tingkat partisipasi masyarakat yang terlibat dalam program dan kegiatan-kegiatan Pokdarwis Wonderful Sangiran menjadi salah satu kunci agar masyarakat dapat menyadari potensi wisata yang ada. Peningkatan partisipasi ini dapat terjadi apabila persoalan mendasar terkait perbedaan persepsi yang berkembang di masyarakat dapat diselesaikan terlebih dahulu. Persepsi masyarakat yang semata hanya terfokus pada dampak ekonomi secara langsung harus diubah menjadi persepsi pengembangan wisata yang berlandaskan pada keberlanjutan ekologis. Agar masyarakat tidak hanya menggantungkan harapan dengan mendapat manfaat dari pihak pemerintah yang mengembangkan kawasan situs Sangiran melainkan mampu mengembangkan secara swadaya berdasarkan inisiatif yang muncul dari masyarakat.

Secara umum, masalah yang dihadapi Pokdarwis terletak pada rendahnya partisipasi masyarakat yang bergabung kedalam organisasi Pokdarwis. Karim, Bambang Jati Kusuma, (2017) menyatakan bahwa untuk mengetahui secara eksplisit peran Pokdarwis dalam mengkampanyekan sadar wisata terhadap wisatawan, masyarakat, maupun dirinya sendiri (para 
anggota),apakah berjalan dengan baik atau tidak, sejauh mana peran mereka dalam melaksanakan atau mengimplementasikan program Sapta Pesona dimasing masing objek wisata.

Dari hasil riset tersebut dinyatakan partisipasi masyarakat secara keseluruhan pada program kelompok sadar wisata di Balikpapan berada pada tahap tokenisme/ tingkah laku positif yang menipu terhadap anggota kelompok yang memiliki kesempatan untuk berpendapat. Mereka tidak memiliki wewenang dan kekuatan untuk mengatur program kegiatan secara keseluruhan meskipun telah dirumuskan ditingkat Pokdarwis.

Suryawan (2016) menemukan juga kendala-kendala yang dihadapi Pokdarwis setempat yaitu kurangnya partisipasi masyarakat dan kurangnya kesadaran serta aktualisasi masyarakat terhadap Sapta Pesona di Desa Tlahap Kecamatan Kledung. Hasil riset tersebut menyatakan bahwa masyarakat belum mengetahui dan belum melihat hasil nyatanya sehingga mereka kurang yakin akan potensi pariwisata Desa Tlahap dapat dikembangkan dan mewujudkan Desa Wisata Tlahap sebagai daerah tujuan wisata.

Dari dua riset penelitian jurnal di atas, masalah yang ditemui adalah rendahnya partisipasi masyarakat bergabung ke organisasi Pokdarwis. Hal ini membuktikan bahwa kehadiran Pokdarwis sangat kurang membina masyarakat lokal untuk dilatih dalam mengembangkan potensi wisata yang ada di daerahnya.

Demikian juga dengan Pokdarwis Wonderful Sangiran, yang di mana rendahnya tingkat partisipasi masyarakat bergabung ke organisasi Pokdarwis. Jika di lihat lebih dalam, kurang efektifnya organisasi Pokdarwis di desa bukan semata-mata dilihat dari programnya saja, tetapi sejauh mana pengurus Pokdarwis mengundang masyarakat berpartisipasi dalam mengembangkan wisata di daerahnya. Kemudian manfaat partisipasi dalam organisasi masyarakat dapat menyatakuan elemen masyarakat untuk mengikis masalah-masalah yang terjadi di desa seperti konflik antar masyarakat yang mengganggu kondusifitas dalam tatanan hidup bermasyarakat.

Jika partisipasi masyarakat ini di prioritaskan, maka sekat-sekat yang selama ini membelenggu persepsi masyarakat akan sendirinya tereliminasi, sehingga masyarakat yang ingin bergabung ke Pokdarwis Wonderful memiliki peran dan fungsi masing-masing guna memanfaatkan potensi lokal wisata di Sangiran. Memang tidak mudah membangun organisasi lokal, dibutuhkan kesadaran kolektif di tataran masyarakat lokal serta diharapkan pengurus Pokdarwis bersinergi dengan pihak BPMSPS, Kepala Desa dan Pemerintah Kabupaten, untuk duduk bersama dalam tingkatan musyawarah guna memutuskan yang berkaitan dengan pengembangan kepariwisataan di Sangiran.

\section{2) Menjalankan Fungsi Koordinasi Dan Komunikasi Antar Lembaga}

Memaksimalkan fungsi koordinasi dan komunikasi di antara pemangku kepentingan dan penerima manfaat merupakan yang kurang saat ini di lakukan oleh Pokdarwis Wonderful. Adanya fungsi kordinasi yang kurang antara Pokdarwis Wonderful dan Kepala Desa selama ini membawa dampak negatif di kalangan masyarakat. Dengan demikian Pokdarwis Wonderful Sangiran dapat menjelaskan tujuan-tujuannya dan pembagian tugas dan peran dengan pihak terkait, sehingga tidak terjadi tumpang tindih kewenangan. Selain itu juga, Pokdarwis Wonderful dapat menjadi mitra yang strategis dan mampu berkolaborasi dengan pihak-pihak terkait dimulai dari perencanaan, implementasi hingga evaluasi dalam rangka pengembangan wisata di Sangiran. Koordinasi dan komunikasi di antara pihak-pihak terkait menjadi sangat penting untuk dilaksanakan dengan inisiatif dari Pokdarwis Wondeful maupun Kepala Desa sendiri supaya tercapainya kesepakatan dalam pengembangan kepariwisataan di Sangiran. Untuk mempermudah fungsi koordinasi, maka forum musyawarah di sepakati sebagai forum tertinggi dalam rangka menyelesaikan msaalah-masalah yang dihadapi yang selama ini menjadi faktor penghambat.

Utami \& Rahman (2017) menyatakan ada beberapa strategi koordinasi kelembagaan yang dilakukan Pokdarwis Kelurahan Kandri dilakukan dalam kegiatan pelestariana Pokdarwis. Koordinasi kelembagaan ini sudah dilakukan dengan baik diberbagai tingkatan meskipun di dalam pelaksanaannya belum maksimal dan masih ditemui beberapa kendala, mulai dari tingkat 
pusat yaitu Kementrian, tingkat Provinsi melalui Dinas Kebudayaan dan Pariwisata Provinsi Jawa Tengah, tingkat kota melalui Dinas Kebudayaan dan Pariwisata Kota Semarang. Masing-masing tingkatan juga melakukan koordinasi dengan usaha jasa pariwisata maupun asosiasi terkait pariwisata lainnya yang selanjutnya diteruskan kepada Pokdarwis dan diteruskan kepada masyarakat di Kelurahan Kandri. Adapun tiga bentuk kordinasi yang dilakukan yaitu :

- Bentuk koordinasi kelembagaan baik ditingkat pusat maupun provinsi yaitu pembinaan yang diberikan kepada Dinas Kebudayaan dan Pariwisata Kota Semarang kepada pokdarwis dilakukan pada awal tahun dengan tiga kali kegiatan, sedangkan dari Provinsi juga melakukan koordinasi dalam bentuk pembinaan kepada pokdarwis sebanyak satu kali kegiatan berupa kegiatan peningkatan SDM.

- Bentuk koordinasi yang dilakukan oleh Dinas Kebudayaan dan Pariwisata Kota Semarang melakukan koordinasi dengan pihak-pihak lainnya seperti SKPD-SKPD dan swasta untuk menunjang kegiatan pelestarian pokdarwis dalam memberikan pembinaan kepada pokdarwis, dinas juga akan melakukan penilaian atau evaluasi kepada pokdarwis.

- Bentuk koordinasi yang dilakukan oleh Pokdarwis dengan seluruh anggota membahas kegiatan dan melakukan evaluasi terhadap kegiatan yang telah dilakukan. Pertemuan ini sifatnya fleksibel dan dilakukan pada saat ada kegiatan saja, dan kegiatan yang dilakukan kurang melibatkan semua warga sehingga peran warga menjadi kurang.

Dari hasil studi tersebut, ada poin yang perlu di aplikasikan pengurus Pokdarwis Wonderful dengan membangun relasi dengan lembaga pemerintah baik pusat maupun daerah yang bertujuan untuk meningkatkan kapasitas pengurus Pokdarwis dan tentunya mendapatan bantuan modal usaha bagi anggota dan masyarakat lokal. Saat ini hubungan Pokdarwis Wonderful dengan pemerintah daerah hanya di tataran legalitas SK. Jika melihat SK yang di terbitkan Dinas Pariwisata, Kebudayaan, Pemuda, dan Olahraga Kabupaten Sragen, seharusnya kerja sama harus ditingkatkan dengan program study banding dan pembinaan rutin oleh instansi terkait. Kemudian Pemda Kab. Sragen harus mampu melakukan lobby( kemudahan) dengan pihak perbankan untuk memberikan stimulus bantuan modal kepada perajin dan pelaku wisata yang berada di Sangiran. Kedepan dengan adanya akses modal yang baik dapat digunakan anggota Pokdarwis untuk mengembangkan wisata di kawasan Sangiran.

Demikian juga dengan hasil penelitian Wijaya et.al (2016) menyatakan ada beberapa strategi yang dilakukan Pokdarwis Maju Mapan untuk memajukan kampung wisata dengan melibatkan berbagai pihak seperti sosialisasi sebagai bentuk tanggung jawab mereka dalam menyadarkan dan membimbing masyarakat akan wisata.

Dalam menjalankan sosialisasinya, Pokdarwis 'Maju Mapan' Desa Bendosari dibantu oleh lembaga desa, seperti PKK, Perangkat Desa, Karang Taruna. Materi disampaikan pada saat kegiatan-kegiatan desa, misalnya pertemuan PKK, musyawarah desa, penyuluhan, kerja bakti. Isi materi di antaranya konsep sadar wisata, Sapta Pesona, diklat kepemanduan Pokdarwis, penanganan hama, manajemen keuangan, homestay sesuai Sapta Pesona.

Setelah dari tingkatan sosialisasi, tindakan yang dilakukan Pokdarwis 'Maju Mapan' Desa Bendosari dalam mengembangkan Pokdarwis seperti melakukan koordinasi, bertukar pikiran dengan berbagai LSM yang berada di Kabupaten Malang, kegiatan sharing antar Pokdarwis lain, mengikuti pelatihan atau seminar seperti Diklat Kepemanduan Ekowisata dari Kementerian Pariwisata, Manajemen Keuangan dan Ekonomi oleh BAPPEDA. Pembentukan dan Pelatihan Kader Lingkungan Hidup oleh Kementerian Lingkungan Hidup dan Kehutanan, Studi Banding ke Desa Wisata Poncokusumo, Pameran Potensi Desa Wisata se Kabupaten Malang oleh Asosiasi Desa Wisata Indonesia (ASIDEWI). Pokdarwis 'Maju Mapan' Desa Bendosari setelah melakukan kegiatan-kegiatan pelatihan, diklat, seminar, maka hasilnya juga di-sharing-kan kepada sesama anggota, masyarakat, dan lembaga desa yang lainnya.

Hasil belajar Pokdarwis "Maju Mapan" Desa Bendosari digunakan untuk mengembangkan Kampoeng Ekowisata Bendosari seperti cafe, kolam pemancingan, rumah pohon, sebagai bentuk pengembangan wahana wisata baru di Kampoeng Ekowisata Bendosari, dan dapat pula sebagai penopang hidup anggota Pokdarwis "Maju Mapan" Desa Bendosari, jadi tidak hanya 
mengandalkan ketika ada tamu saja. Solusi yang ditempuh akan dana, sedang diusahakan dengan pengembangan wahana wisata, solusi seandainya tidak ada dukungan dari Pemerintah Desa, Pokdarwis harus mampu bergerak sendiri, solusi tentang SDM, Pokdarwis ingin melibatkan pemuda lebih banyak lagi di tiap dusun agar lebih bermanfaat dan berkembang. Dukungan yang diterima Pokdarwis "Maju Mapan” Desa Bendosari dari swasta belum ada, sebagian besar masih dari pemerintah dan masyarakat.

Dari hasil jurnal di atas, sangat di sarankan kerja sama lintas sektoral yang melibatkan para pegiat wisata yang berada di Kabupaten Sragen maupun di Provinsi Jawa tengah. Proses sharing pengalaman dan belajar cara mengelola kawasan wisata sangat bermanfaat untuk dikembangkan di Sangiran. Hubungan komunikasi antar lembaga dapat dilakukan terlebih dahulu, jika adanya keseriusan dari pemimpin organisasi.

Begitu juga dengan peran dan fungsi lembaga mitra strategis Pokdarwis Wonderful, BPSMPS yang berada di kawasan Sangiran. Kehadiran lembaga BPSMSPS perlu di tingkatkan melalui kerja sama. Saat ini komunikasi yang kurang efektif timbul akibat adanya dugaan dan prasangka. Dugaan /prasangka ini berkembang adanya kesalahan informasi di masyarakat Sangiran yang memahami BPSMPS dianggap dapat memberikan manfaat ekonomi ke masyarakat lokal. Padahal jika dilihat nomenklatur kelembagaan, kehadiran BPSMPS sebagai pengelola museum terintegrasi dengan Kementrian Pendidikan dan Kebudayaan.

Pola kerja sama ini tentu ditingkatkan dan tidak hanya berada dalam tingkatan kerja sama penggalian/eskavasi fosil, tetapi perlu diperkuat kembali melalui edukasi dan jejaring yang dimiliki BPSMPS. Hubungan kerja sama kemudian di lebur menjadi bentuk program revitalisasi wisata seperti bekas penggalian fosil yang nantinya di desain menjadi wisata eskavasi, kemudian kerja sama pemasaran hasil kerajinan (suvenir) yang bertema budaya dan fosil, sehingga wisatawan maupun peneliti dapat memahami keunikan alam Sangiran.

\section{3) Transformasi Pengelolaan Organisasi}

Pengelolaan organisasi Pokdarwis Wonderful Sangiran dapat berjalan sesuai yang diharapkan jika ada kekompakan dan visi bersama guna pengembangan kepariwisataan di Sangiran. Ketua Pokdarwis Wonderful harus mampu menerjemahkan visi organisasi Pokdarwis sebagai program kerja yang di dalamnya terdapat 7 unsur Sapta Pesona yang nantinya digunakan sebagai panduan bagi wisatawan maupun masyarakat lokal tanpa melupakan kebiasaan masyarakat lokal Sangiran. Kemudian hal yang mendasar untuk dikembangkan Pokdarwis Wonderful adalah kolektivitas kader organisasi dan pendistribusiannya sesuai dengan kebutuhan organisasi. Dengan metode tersebut, kelamahan mengelola organisasi dan kurangnya program selama ini akan sendirinya masuk ke dalam sistem ini, sehingga landasan 7 Sapta Pesona menjadi kebiasaan bagi masyarakat Sangiran dalam menjalankan aktivitasnya.

Sebagai perbandingan, hasil riset Permadi et.al (2020) menunjukkan bahwa Pokdarwis Bonjeruk melakukan kegiatan pelatihan manajemen pemasaran pariwisata dengan materi :

1. Pemahaman Produk Wisata Sejarah

2. Pembuatan Paket Wisata, Penetapan harga dan promosinya yang terdiri dari :

a. Membuat rencana bisnis wisata

b. Membuat kemasan paket wisata sejarah Bonjeruk, Tour de Jonggat dan paket soft tracking, Para peserta pelatihan diberikan pengetahuan dan pemahaman tentang prinsip-prinsip dasar dalam menyusun paket wisata sejarah, paket Tour de Jonggat dan paket tracking, yaitu menyangkut rute perjalanan.

c. Pelatihan membuat brosur. Peserta pelatihan juga dilatih cara membuat brosur paket agrowisata. Pelatihan kegiatan pembuatan brosur ini dilakukan melalui dua tahap, yaitu :

- uji coba paket yang ditawarkan dengan menyusuri lapangan dan objek sacara langsung pembuatan brosur paket wisata sejarah

- Pembuatan perangkat promosi yang terdiri dari baliho dan spanduk dengan menggunakan Corel Draw dan Adobe Photoshop. 
Dari hasil jurnal ini ditemukan peningkatan kinerja kelompok sadar wisata dengan pendampingan dan evaluasi peningkatan kinerja organisasi dengan hasil :dibuatnya brosur dan kartu nama kelompok, peningkatan jumlah anggota aktif yang terbukti dari masuknya 31 orang penggiat seni Desa Bonjeruk sebagai anggota divisi atraksi seni dari kelompok sadar wisata tersebut, dibuatnya neon box yang dipasang di depan sekretariat kelompok sadar wisata itu, berhasil mengorganisir Promosi Memaos Takepan dengan Grup Cempaka Wangi yang dihadiri oleh Kepala Dinas Kebudayaan dan Pariwisata Lombok Tengah.

Dalam jurnal di atas, hal yang mendasar adalah kebersamaan dan adanya evalusasi dan pendampingan. Dengan evaluasi lembaga secara berjangka dan rutin, maka diharapkan organisasi Pokdarwis Wonderful menuju pada sebuah menejemen organisasi yang berinovasi sesuai dengan cita-cita pengembangan kepariwisataan di Sangiran. Disamping itu, transformasi kepengurusan juga tidak kalah penting dan dapat dimulai dari perekrutan kader. Mekanisme kaderisasi dapat dilakukan dengan melihat jiwa kepemimpinan dan tanggung jawab kader melindungi Sangiran serta adanya kaderisasi berjenjang dalam mengelola organisasi yang dimulai dari anggota klaster hingga pengurus organisasi Pokdarwis Wonderful.

Sementara itu, dalam pengambilan keputusan rapat dan evaluasi sangat dipandang perlu di bahas dalam forum resmi yang di fasilitasi Pokdarwis maupun lembaga pemerintah. Proses rapat dan musyawarah harus dapat mengedepankan karakteristik pada nilai-nilai Sangiran, sehingga masalah konflik pribadi dan evaluasi program kerja Pokdarwis Wonderful dapat diselesaikan dengan pendekatan budaya.

Hasil riset Putra (2013) menyatakan faktor yang berpengaruh dalam keberhasilan pengembangan Desa Wisata Tembi adalah keberadaan Pokdarwis sebagai suatu institusi lokal yang bertanggung jawab untuk menjamin progress desa wisata. Pokdarwis ini memiliki struktur organisasi yang terdiri dari para pengurus harian (ketua, sekretaris, bendahara, dan ketua-ketua seksi) dan anggotanya masyarakat Desa Tembi. Pengaruh para pengurus harian ini terbilang kuat dalam mengatur setiap aktivitas yang berhubungan dengan pengembangan desa wisata. Meskipun demikian, kehadiran masyarakat sebagai anggota Pokdarwis tetap penting sebagai panduan para pengurus harian dalam pengambilan keputusan agar sejalan dengan kebutuhan masyarakat. Salah satu peran dari Pokdarwis yang memiliki pengaruh nyata dalam mendukung perkembangan Desa Wisata Tembi adalah berhasil meningkatkan kualitas dan kuantitas program-program atraksi wisata, yang disuguhkan kepada para wisatawan.

Hasil penelitian ini menunjukkan bahwa adanya strategi pengembangan wisata seperti atraksi wisata yang berhasil dibuat seperti seni tari, musik karawitan, pertunjukan musik bangbung (alat musik dari bambu), gejog lesung (aktivitas tumbuk gabah), permainan tradisional anak-anak, kerajinan handycraft, ragam kuliner, dan edukasi kegiatan menanam atau memanen padi. Progres atraksi wisata yang ada di Desa Wisata Tembi memang banyak mendapat apresiasi dari para wisatawan yang berkunjung di sana. Kemudian adanya bentuk-bentuk atraksi wisata baru menandakan bahwa pengurus Pokdarwis bisa bekerja sama dengan baik dalam mengupayakan suatu hiburan baru guna menarik lebih banyak minat dari wisatawan, baik wisatawan mancanegara maupun lokal. Sedangkan pembuatan atraksi wisata baru ini dari hasil diversifikasi dan modifikasi atraksi wisata yang lama menandakan bahwa para pengurus Pokdarwis sedang melakukan upaya pelestarian budaya kebudayaan Jawa yang ada di Tembi.

Kawasan daerah Sangiran tidak terlepas dari peran dan fungsi budaya lokal Jawa. Karakterstik budaya merupakan bagian kehidupan sehari-hari dapat dilakukan dalam pengambilan keputusan maupun program pengembangan wisata di Sangiran. Dari jurnal di atas dapat dilihat bagaimana keberhasilan organisasi Pokdarwis di Desa Tembi mengintegrasikan industri kreatif degan ragam kesenian daerah yang mampu mengangkat nilai dan budaya Jawa. Keberhasilan terebut tidak terlepas dari peran pengurus dalam memetakan potensi lokal dalam program kerja Pokdarwis sebagai bagian dari esensi organisasi Pokdarwis di desa Tembi.

Begitu juga dengan Sangiran yang memiliki sejarah panjang pengakuan UNESCO tidak terlepas dari peran masyarakat lokal Sangiran. Pokdarwis Wonderful sebagai penjaga warisan dunia harus merawat nilai-nilai budaya dalam pengembangan wisata. Kekayaan budaya Sangiran seperti cerita balung buta, cerita legenda Joko Tingkir dan banyak lagi cerita rakyat yang turut 
serta melahirkan Sangiran sebagai situs warisan dunia. Hal yang mendasar dalam pengembangan atraksi budaya di butuhkan kerja sama dan kesadaran koletif masyarakat lokal tanpa melupakan kreativitas dan inovasi dalam pembangunan kepariwisataan di Sangiran.

4) Model Pengembangan Kepariwisataan Pokdarwis di Sangiran

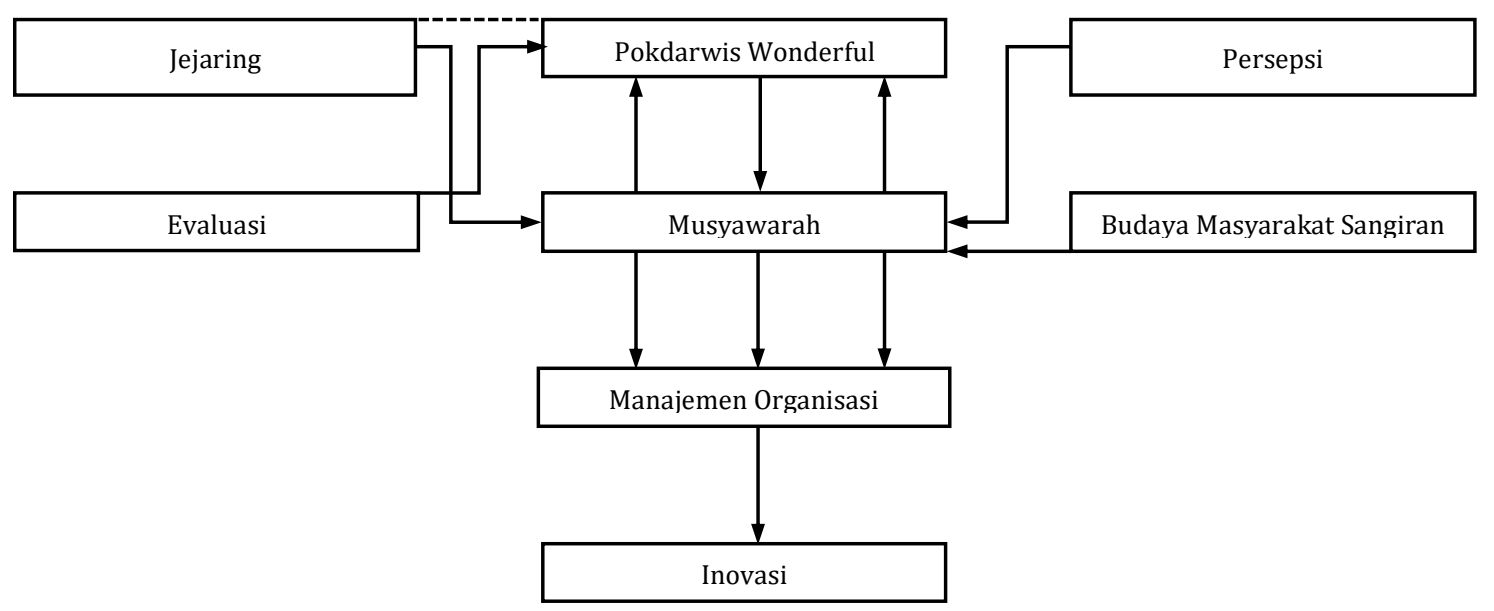

Gambar 1. Model Pengembangan Kepariwisataan di Sangiran

Untuk mengembangkan organisasi Pokdarwis Wonderful Sangiran dibutuhkan kerja sama dengan lembaga atau jejaring yang berada di Sangiran. Jejaring dalam hal ini pihak BPSMP Sangiran, Kepala Desa se kawasan Sangiran diharapkan hadir dalam pengembagan wisata dalam musyawarah yang dilakukan Pokdarwis Wonderful. Musyawarah merupakan sarana tertinggi untuk memutuskan program dan juga disubtitusi sebagai wadah evalusasi bagi pengurus Pokdarwis Wonderful. Tidak menutup kemungkinan juga usul dan saran dari Kepala Desa dan Dinas Pariwisata, Kebudayaan, Pemuda, dan Olahraga Kabupaten Sragen dalam forum musyawarah tersebut. Model pengembangan ini tentunya sebagai solusi yang akan dilakukan dalam pengembangan wisata di Sangiran .

Keterangan :

1. Organisasi Pokdarwis berperan sebagai wadah bagi kelompok masyarakat dan pelaku wisata yang memiliki persepsi yang sama guna pengembangan kepariwisataan di Sangiran.

2. Dalam ruang penyampaian gagasan, semua usul dan saran ditampung di dalam wadah musyawarah dengan pertimbangan karakteristik budaya lokal Sangiran.

3. Dalam musyawarah, program perencanaan di putuskan di dalam musyawarah dengan memerhatikan arah dan strategi pengembangan wisata di desa Sangiran dan aktor pelaksanaan program diberikan wewenang kepada organisasi Pokdarwis Wonderful.

4. Setelah di bahas di musyawarah, Pokdarwis Wonderful akan melaksanakan program kerja dengan kemampuan menejemen organisasi yang dimiliki untuk melahirkan sebuah inovasi dalam pengembangan kepariwisataan di Sangiran.

\section{Simpulan dan saran}

Saat ini organisasi Pokdarwis Wonderful belum mampu untuk mengkonsolidasikan dan mengomunikasikan tujuannya dalam pengembangan kepariwisataan di Sangiran. Lemahnya inovasi dan kurangnya aksi dan terobosan pengurus Pokdarwis Wonderful berpotensi pada fase stagnan dan kurang berdampak pada kawasan Situs Manusia Purba Sangiran. Dibutuhkan langkah-langkah strategis untuk mengatasi hambatan-hambatan yang dihadapi oleh Pokdarwis Wonderful baik yang ada di internal maupun di luar organisasi. Kehadiran Pokdarwis Wonderful dapat dimaknai sebagai jejak sejarah yang melahirkan banyaknya persepsi yang berbeda-beda di masyarakat tentang potensi yang terkandung di dalamnya. Dalam hal ini persepsi masyarakat lokal melihat kawasan Situs Sangiran terbagi, ada yang melihat dalam aspek ekonomi, dan ada dengan sikap apatis dan ada hanya melihat Sangiran hanya sebagai museum semata. Persepi ini 
turut memengaruhi komunikasi di antara pemangku kepentingan dan Pokdarwis Wonderful dalam membangun kepariwisataan di Sangiran.

Kepala Desa sebagai tokoh sentral diharapkan sebagai mediator dalam menyelesaikan masalah di organisasi Pokdarwis, terlepas siapa saja lembaga yang menerbitkan SK pengurus Pokdarwis Wonderful. Kepala Desa sebagai pemimpin tertinggi diharapkan netral dan mampu menguatkan organisasi, sehingga masyarakat lokal bersedia bergabung ke organisasi Pokdarwis Wonderful. Serta diharapkan Kepala Desa memiliki keinginan untuk menyelesaikan konflik dengan duduk bersama tokoh masyarakat tanpa melihat jabatan atau identitas yang melekat dalam diri masing-masing. Inisiatif ini menunjukkan terbukanya peluang untuk menyelesaikan konflik yang ada karena pihak Pokdarwis Wonderful sendiri dapat menyambut baik inisiatif tersebut. Dinas Pariwisata, Pemuda dan Olahraga Kab. Sragen sebagai unsur pemerintah kabupaten harus benar-benar hadir di tengah masyarakat dalam pengembangkan wisata di Sangiran. Kehadiran pemerintah Kabupaten sangat diharapkan Pokdarwis Wonderful terutama menangani masalah-masalah organisasi serta membantu penguatan kapasitas pengurus organisasi Pokarwis Wonderful. BPSMP Sangiran sebagai mitra strategis, diharapkan tetap memberikan edukasi dalam bentuk pelatihan-pelatihan serta jaringan (networking) untuk dapat membantu organisasi Pokdarwis Wonderful memasarkan kerajian tradisional dan membantu meningkatkan kreativitas dan inovasi kader organisasi Pokdarwis Wonderful.

\section{Ucapan terimakasih}

Penulis mengucapkan terimakasih kepada UKSW Salatiga yang telah mendanai penelitian ini melalui penerimaan beasiswa Notohamidjojo Award tahun 2018, SK Rektor No: 576/BS/REK/3/Pelma/IX/2018.

\section{Daftar Rujukan}

Creswell, J.W. (1998). Qualitative Inquiry And Research Design: Choosing Among Five Traditions. London: SAGE Publications.

Creswell, J.W. (2016). Research Design Pendekatan Metode Kualitatif, Kuantitatif, dan Campuran. Yogyakarta: Pustaka Pelajar.

Djumiarti, T. (2020). Accountability Assessment of Tourism Awareness Group (Pokdarwis) from Governance Paradigm (Case Study of Pokdarwis Wonderful Sangiran Indonesia). https://doi.org/10.4108/eai.21-10-2019.2294452

Dunn, W. N. (2003). Pengantar Analisis Kebijakan Publik. Yogyakarta: Gadjah Mada University Press.

Haque, M. (2000) 'Environmental Discourse and Sustainable Development', dalam Ethics and the Environment. 5(1):3-21.

Hikmat, H., 2004. Strategi Pemberdayaan Masyarakat. Bandung: Penerbit Humaniora.

Johnson, D.P. (1990). Teori Sosiologi: Klasik dan Modern (Jilid II). (Diterjemahkan oleh R. M.Z. Lawang). Jakarta: Gramedia.

Karim,S, Kusuma B.J, Amalia, N. (2017). Tingkat Partisipasi Masyarakat Dalam Mendukung Kepariwisataan Balikpapan : Kelompok Sadar Wisata (Pokdarwis). Bisnis dan Kewirausahaan 13(3) : 144-155.

Murphy, P.E. (1988) Community Driven Tourism Planning. Tourism Management 9 (2)

Permadi, L. A. et al. (2020) "Peningkatan Kinerja Organisasi Kelompok Sadar Wisata di Desa," jurnal.lppm.unram.ac.id/index.php/jurnalpepadu, 1(1), hal. 85-89.

Putra, T. R. (2013) "Peran Pokdarwis dalam Pengembangan Atraksi Wisata di Desa Wisata Tembi, Kecamatan Sewon-Kabupaten Bantul," Jurnal Pembangunan Wilayah \& Kota, 9(3), hal. 225. doi: $10.14710 /$ pwk.v9i3.6522.

Rahim, F. (2012) Buku Pedoman Kelompok Sadar Wisata. Jakarta: Kementerian Pariwisata dan Ekonomi Kreatif

Rara Sugiarti, Warto, \& Sutirto, T. W. (2019). Partisipasi Pemangku Kepentingan Dalam Mendukung Revitalisasi Aset Wisata Pusaka Di Kawasan World Heritage Sangiran. Journal of Chemical Information and Modeling, 53(9), 1689-1699. 
Sastroputro, S. R. A. (1988). Partisipasi, Komunikasi, Persuasi, dan Disiplin dalam Pembangunan Nasional, Bandung: Alumni

Sémah, F, Sémah, A.M; Djubiantono, T. 1990. Mereka menemukan pulau Jawa; Lebih dari satu juta tahun lalu [...] Jakarta: Pusat Penelitian Arkeologi Nasional (Jakarta) dan Muséum National D’Histoire Naturelle (Paris).

Simanjuntak, H.T. 2005. "Sangiran dalam perspektif penelitian”, Jurnal Arkeologi Indonesia 4: 1324.

Sulistyanto, B. (2009) “Warisan dunia Situs Sangiran,” Wacana, 11(1), hal. 57-80.

Suryawan, A. (2016) "Peran Kelompok Sadar Wisata (Pokdarwis) Sendang Arum Dalam Pengembangan Potensi Pariwisata (Studi Kasus Di Desa Wisata Tlahap Kecamatan Kledung Kabupaten Temanggung)," Jurnal Elektronik Mahasiswa PLS, 5(6), hal. 143-152.

Undang-Undang Republik Indonesia No 11 tahun 2010 Tentang Cagar Budaya. Jakarta : Sekretariat Negara Republik Indonesia.

Utami, A. N., \& Rahman, Z. (2017). Pelaksanaan Progam Kampanye Sadar Wisata dan Sapta Pesona melalui Pelestarian Kelompok Sadar Wisata ( Pokdarwis ) di Kelurahan Kandri Kecamatan Gunungpati Kota Semarang. Journal of Public Policy and Management Review, 6(2), 1-15.

Wijaya, S. A., Zulkarnain dan Sopingi (2016) "Proses Belajar Kelompok Sadar Wisata (Pokdarwis) Dalam Pengembangan Kampoeng Ekowisata,” Jurnal Pendidikan Nonformal, XI(2). 88-96. 